\title{
Standard Breton, traditional dialects, and how they differ syntactically
}

\author{
Pre-final version - second submission to JCL janv. 2019
}

\begin{abstract}
:
This article provides a first attempt of a syntactic characterization of the different Breton varieties spoken in the twenty first century. Standard Breton is addressed as one of the modern dialects spoken in Brittany, and its syntax is compared with that of traditional varieties. I first establish a baseline and inventory the syntactic parameters that differentiate the traditional dialects from each other: Kerne, Leon, Goelo, Treger (KLT in the West) and Gwenedeg (South East). I show that a robust body of syntactic variation facts characterizes traditional dialects. I next compare these with the Standard variety that emerged during the twentieth century, and show that if Standard Breton has original features of its own, it varies less with respect to traditional varieties than traditional varieties among themselves.
\end{abstract}

\section{Goal of the article and methodology}

Comparative studies of Breton dialects address phonology, lexicon, and sometimes morphology, but rarely syntax. When it does, the literature shows a striking lack of consensus concerning the syntactic distance between spoken Breton varieties illustrated in (1). The first question is the extent of syntactic variation across traditional Breton dialects. The second question is the syntactic distance between, on the one hand, all and each of these traditional varieties and, on the other hand, Standard Breton in its written and oral varieties.

(1)

\begin{tabular}{|c|}
\hline \multicolumn{2}{c}{ Traditional varieties } \\
Goelo \\
Leon
\end{tabular}

Kerne

Gwenedeg

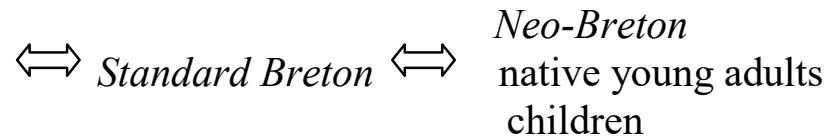

children

I consider in (1) only varieties produced by fluent native speakers, independently from the estimated number of these speakers. These varieties can be oral or written, for both traditional varieties and Standard. The sources thus include both elicitation and corpus examples, written and oral.

\footnotetext{
${ }^{1}$ This work benefited from comments of Milan Rezac, Stefan Moal and two anonymous reviewers, whom I thank here. Possible remaining errors are mine. Elicitation data cited from Jouitteau (2009-2019) is signaled in squared brackets as name of native speaker [date of elicitation], and can be consulted online at www.arbres.cnrs.iker. First submission oct. 2017, two reviews received oct. 2018.
} 
This article will not be concerned with Neo-Breton in (1). Consequently, I leave here open whether Neo-Breton diverges from contemporary Standard Breton that emerged in the literature and media during the twentieth century. I set aside as well acquisition data of children in schools and preschools. Finally, I set aside learning mistakes of second language learners of various proficiency. The study of language evolution, language acquisition or second language phenomena cannot do without a baseline study of the actual variation across native dialects, including Standard. This paper aims to provide such a baseline. I concentrate here on the study of syntactic variation among traditional varieties and Standard Breton.

In this work, Standard Breton refers to the forms of the language as used in the media and in education in twenty first century Brittany, notably by the Public Office of the Breton language and by all the forms of publications supported by the Region Bretagne. This covers all syntactic structures in Breton who cannot be tied to a particular geographical variety. I consider both written and spoken forms. Standard Breton has a long history as a written form. I do not assume a-priori that there are no native speakers of it. On the contrary, I will present data from elicitation with speakers demonstrating native competence both in their traditional variety and in Standard Breton, sometimes with quite a good proficiency at distinguishing the two. ${ }^{2}$

Lack of distinction between the above Breton varieties in (1) has lead to much confusion in the literature, so let me illustrate with one concrete example. Hornsby (2005:fn8) contrasts tag-questions like deo, in dialectal Breton (a notion conflating all traditional varieties) and the use of neketa /is.not.then/ that he associates with neoBreton (a notion conflating Standard Breton, neo-Breton as spoken by younger generations schooled in Breton, as well as second language productions and errors). He proposes that neketa is a calque on French n'est-ce pas?, which automatically raises important questions about French influence in emerging varieties. Distinguishing among Breton varieties in (1) allows to distinguish among traditional varieties, and to consider for each their respective distance with respect to Standard Breton. Syntactic invariants emerge. Tag questions in every variety depend on the matrix clause being positive (triggering a negative tag like neketa), or negative (triggering a positive oppositive tag like deo). The form of tag questions in each context varies across traditional varities.

Positive tag questions are documented in the following forms. In Bear in Treger with speakers born at the beginning of the twentieth century, Yekel documents repetition of the matrix verb without its negation preceded by a /g-/ prefix (2), repetition of its infinitive (3) or use of the inflected auxiliary do with most lexical verbs (4). In some varieties, eo can serve as a default choice for other matrix verbs than the verb 'to be'. Derivatives of the eo form are also found. The deo form pointed out by Hornsby is a variation of geo showing the same / $g$-/ prefix as in (2). The variant neo is found in Enez Sun (Fagon \& Riou 2015:44), or ea in Plozevet (Goyat 2012:284).

Negative tag question Neketa, literally /is not then/, is documented following positive matrices in traditional varieties of Leon (5), and in Enez Sun under the form keda (6). It

\footnotetext{
${ }^{2}$ German (2007) diachronically distinguishes between different forms of Standard: on the one hand, the ecclesiastic norms in Leon and Gwened, that is Standards as "conceived by native Breton-speaking priests during the ninetieenth century", and on the other hand a "highly prescriptive form of the literary language which is characterized by linguistic purism and hypercorrective tendencies (elimination of French linguistic influence)" which he calls new Standard. The present study is only concerned with the product of these standardization processes, that is the varieties produced by the different age groups in Brittany at the beginning of the twenty first century.
} 
follows that the use in Standard of neketa as a tag question, as documented in (7) by the Public Office of the Breton language, does not reveal more French influence than its use in traditional varieties. At most, it illustrates a general bias of Standard towards the particular native variety of Leon.

(2) N'eus ket trawalc'h evit ober gwin ivez, geus? Treger (Bear), Yekel (2016) neg is not enough for to.do wine too $/ \mathrm{G} /+$ is 'There is not enough to make also wine, is it?'

(3) Toennoù plouz ne vo ket adkomañset dont ken, bez? roofs straw neg will.be not again.start come anymore to.be 'Thatched roofs won't come back, will they?'

Da vamm ne gaozea ket brezhoneg diouzhit, gra?

Your mum neg speaks not Breton to.you, does.she 'Your mother does not speak to you, does she?'

Leon, Seite (1998:22)

(5) Amañ, war gern Menez-Hom e vez eur gouél braz, bep ploaz, neketa! here on summit Menez-Hom prt is a party big each year neg.is.not.then 'Here, on the summit of Menez-Hom there is a party every year, isn't there!'
Ervoa 'di ar meurd keda?
today is the tuesday (is).not.then
'Today is Tuesday isn't it?'
Iskis eo an aerouant-mañ, neketa?
Standard
strange is the dragon-here neg.(is).not.then
'Don't you find this dragon strange?'

Enez Sun, Kersulec (2016:30)

I will show in this article that syntactic variation across traditional varieties is so extensive that extreme caution is in order when claiming that a particular structure does not exist in traditional varieties. This means that methodologically, a given expert and/or native speaker of a given dialect can only attest to the existence or absence of a phenomenon in that particular dialect. In order to prove that a given syntactic phenomenon attested in Standard Breton is unique to it, one has to check it against the considerable variation attested across traditional varieties.

Most characterizations of distance between dialects so far rely on intercomprehension (Merser 1963:ii, Stephens 1982, among others). Stephens (1982:3), a native speaker of the Treger dialect, cites three points of syntactic dialectal variation: (i) the system of preverbal particles (rannigoù), (ii) the system of proclitic object pronouns and (iii) the complementizers $p a$ 'when' and $m a$ 'that'. She claims that other than that, "the syntax of the dialect of Bro-Wened does not differ dramatically from the others as can be judged from the grammar and the text books by Guillevic \& Le Goff [1986] and by Herrieu [1994]. The difference between the dialect of Bro-Wened and KLT Breton [Kerne, Leon Treger] is very pronounced at the phonological level, including a stress on the ultimate syllable in Bro-Wened whereas in the others stress is still on the penultimate". The opposite view proposes that there are deep differences across dialects and also relies on intercomprehension, or more precisely on a lack thereof (see German 2007:148, Le Berre and Le Dû 2015, Hewitt 2016, among others). The findings of the two approaches are thus diametrically opposed.

However, lack of intercomprehension need not be attributed directly to the syntactic dimension of the message, as it may be due to morphology, prosody or even discourse pragmatics. Claims of intercomprehension are also deeply subjective, and prone to the 
influence of extra-linguistic factors. More than linguistic divergence proper, they reveal the goodwill, politeness, linguistic representations, literacy, social status, linguistic confidence, political orientation, audition and/or multilingualism of the speakers, as well as what they think supports best the beliefs of their interlocutor. All these factors also typically interact with gender differences. Consider the case of Yvonne BriantCadiou of Plouzane in Leon, who married at the beginning of the twentieth century a man born and raised $7 \mathrm{~km}$ away in Kerber (now Saint-Pierre-Quilbignon), under the influence of the French speaking metropolis of Brest. She writes: "All these men [soldiers or priests] spoke only Breton when they were together. So my husband, who used to speak French at home, understood the Breton of Leon, Treger and even the Breton from Côtes-du-Nord [Goelo/Treger/Kerne Uhel?] and from Morbihan [Gwenedeg], which I find very hard". This Breton native speaker of Leon did not have access to the male socialization that would have provided her with dialectal flexibility, in contrast with her husband. Although very interesting for its sociolinguistic dimensions, this testimony tells us nothing about syntactic divergence or convergence of these varieties. ${ }^{3}$

In this debate, I consider that the differencialist view of dialects bears the burden of the proof, because providing evidence for a contrast is methodologically easier and less time consuming than proving persistent convergence between two linguistic varieties. Consequently, in the following, I inventory the syntactic dialectal features proposed in Avezard-Roger (2004a,b, 2007), Hornsby (2005), Rezac (2008), Jouitteau \& Rezac (2008, 2009, forthcoming) and Kennard (2013), as well as in Jouitteau (2009-2019) which provides a synthesis of the syntactic features mentioned in various monographs on local varieties, crosschecked with corpus and elicitation data. This overview is of course far from exhaustive, but it is sufficient to clearly reveal a robust body of syntactic variation across the traditional dialects. ${ }^{4}$

\section{Quantification of the syntactic variation in traditional varieties}

Quantifying variation is a difficult task, and for a first approach, I propose to inventory the functional material available to each variety. I define a syntactic point of variation as the presence or absence of a functional head that affects syntax (word order, agreement, case assignment, resumption or movement). As for morphological variation, it participates in syntactic variation only when it correlates with an element's restriction on distribution or on interpretation. I include in my analysis phonologically nul elements like empty pronouns, empty complementizers or empty negation, as long as they are recoverable by interpretation or by evidence of syntactic interaction with them (null subjects for example are recoverable by verbal agreement with them).

\footnotetext{
${ }^{3}$ Briant-Cadiou (1998:103-4): “An oll baotred-se [soudarded pe veleien] pa vezent kenetrezo ne gomzent nemed brezoneg. Setu va gwaz din-me, hag a oa kustum da gaozeal galleg er gêr, a gomprene brezhoneg Leon, Treger ha Kerne, ha zoken hini ar Hot-du-Nor hag ar Morbihan, ar pez em-beus kalz poan oh ober", our translation.

4 There is also a lack of consensus concerning the genesis of dialectal differentiation. According to Jackson $(1967: 6,33)$, the divergence of the modern dialects happened after late Middle Breton. Falc'hun (1951) considers Gwenedeg to come from Gaulish and the KLT dialects from a Brittonic revitalization, Fleuriot (1982:269) traces back the differenciation of Gwenedeg to the XII ${ }^{\circ}$ th century and the later differentiation of $\mathrm{KLT}$ dialects to the $\mathrm{XVI}^{\circ}$ century. I do not adress these diachronic issues here.
} 
In this section, I will dress an inventory the main points of variation in the syntactic structure across dialects. I will proceed from the higher levels of the clause (complementizers) to the lower levels (verbal, prepositional and nominal domains). I will next address agreement patterns and restrictions on movement. In the last part, I consider variations of semantic interpretation that relate to syntactic variations.

\section{II.1. Complementizer domain}

Grammaticalization is an important source of functional material in a language, and innovations that are not shared across dialects become dialectal markers. The concessive complementizer nabochdou or na bout 'even if' marks South-East dialects (East Kerne and Gwenedeg) because it is absent from other dialects. These two forms are grammaticalized from na boût 'zo Doue /even to.be is God/ (8). Most Breton dialects have only one declarative complementizer 'that' which has no phonological matrix (null complementizer). Central dialects however make use of two additional overt declarative complementizers 'that', la(r) from lavarout 'to say', as shown in the East Kerne example in (8), and penaos from the interrogative 'how', attested at least since Middle Breton. These two grammaticalisations have spread in different areas East and West, and they can co-occur, as in Uhelgoat (9), which creates a sharp contrast with the null complementizer used in other dialects. The two central Breton complementizers la(r) and penaos impact word order as they favour embedded verb-second orders (10).

Na boût 'zo Doue'oa flaer gantañ, ne oa ket dav larout lar 'oa flaer. even.if was smell with.him neg was not modal to.say that was smelly 'Even if he smelled bad, it was not advisable to say so.'

East-Kerne (Rieg), Bouzeg (1986:III)

Gwelet e-meum abaoe lar penaozne oa ket gwir.

seen prt-have.1PL since that that NEG was NEG true

'We have seen since that it was not true.' Uhelgoat, Skragn (2002:100)

Dre ar bourke rede ar brud penôs lestr Kola F. ar Guez a oa bet kollet. across the town prt ran the news that ship Kola F. ar Guez prt was been lost 'In town was heard the news that the ship of Kola F. ar Guez had been lost.'

West Treger, Al Lay (1925:17)

Interrogatives are well-known dialectal markers because of their morphological variation and relative ease of grammaticalization, for example manner interrogative : pegiz, penaos, peseurt mod, peneuz (Le Roux 1927:map 519) or temporal interrogative : peur, pedavare, pelare, pevare, pezavare, /pøz'va:re/, /poxeir/, e pezh kours, pegoulz (Le Roux 1927:map 518)... This morphological variation however does not impact word order because the interrogative always comes first. Only Gwenedeg distinguishes the locative interrogatives of provenance and destination (peban and emen, or in the Groe island /zo-men/ and /imen/, Ternes 1970:227). This changes the functional inventory of interrogatives in this dialect. Only KLT dialects feature the optional semantically empty preposition $d a$ in interrogative sentences (Kervella 1947:§761, Gros 1970:157), as illustrated in (11).

Petra d'ober gant ur mennig?

Kerne (Pleyben), Ar Floc'h (1950:62)

what to to.do with a goat.kid

'What to do with a goat kid?' 
In all dialects, polar questions can be realized by a raising intonation. The alternative is a segmental Q head found under different forms: daoust, a grammaticalisation of /to know/, daoust hag, daoust hag-eñ, hag-eñ or ha(g). Not all options are available for all speakers. H. Gaudart [04/2016b] in Skaer/Bannaleg for example recognizes no form of daoust, and uses $h a(g)$ followed by a verb-second sentence (Q-XP-V), as does Stephens in (12). Leclerc in Treger can use daoust $h a(g)$ followed or not by the inflected verb (Q(XP)-V) as in (13)a. For Central Breton and Treger, Wmffre (1998:44) and Gros (1970:25) use daoust hag-eñ immediately followed by the verb. The eñ element is homophonous with a 3SGM independent pronoun. It is a last resort filler before the verb: nothing can separate it from the verb $(\mathrm{Q}-e \tilde{n}-\mathrm{V})$. There also exists a competing form c'hwistim, grammaticalization of /you think/, which is restricted to Treger-bihan and Goelo (Leclerc 1986:205, Koadig 2010:91). Use of c'hwistim impacts word order because it allows omitting the complementizer hag as in (13)c, which is impossible for the same speaker with daoust. In Kerne, Trépos can use a complex doubled form followed by verb-second (Q-XP-V) as in (14), whereas Western Gwenedeg makes use of a French borrowing immediately followed by the tensed verb $(\mathrm{Q}-(* \mathrm{XP})-\mathrm{V})$ as in $(15)$. 5

(12) Ha dont a raio dager?

$\mathrm{Q}$ to.come prt will.do to home

'Will he come home?'

(13)a. Daoust hag(-eñ) ec'h $i$ da Bariz ?

Treger, Stephens (1990:163)

b. C'hwistim hag(-eñ) ec'h $i$ da Bariz?

c. C'hwistim ec'h $i$ da Bariz?

Q C-3SGM prt will.go to Paris

'Will you go to Paris?'

(14) Ha (daoust ha) klañv oc'h?

Kerne, Trépos (2001:§381)

$\mathrm{Q}$ to.know $\mathrm{Q}$ sick are

'Are you sick?'
[esko so ta:w
ве be:w ]
Western Gwenedeg, Cheveau (2007:213)
Esk 'zo atav re bev
$\mathrm{Q}$ is always $\mathrm{N}$ alive
'Is there always some that are alive?'

Answers to polar questions use strategies parallel to those seen above for tag questions, and they are subject to a rich dialectal variation, which for reasons of space I leave here aside. I turn now to embedded Q particles. These can never be realized by intonation only. Their segmental realization varies. Most dialects use ha(g) or hag-eñ. The conditional complementizer $m a$ 'if' is also recruited as an embedded Q head 'whether' (16) and has been spreading across dialects since the beginning of the twentieth century (see Jouitteau 2009-2019:'Q' and references therein). Example (16) also shows that the declarative complementizer $l a(r)$ of central and South-Western dialects can also appear before the embedded Q head, or alone as the only realized Q head. The dialect of SaintYvi has grammaticalized hag-eñ into an opaque nasalized form restricted to embedded domains (17). In Le Juch, 30 kilometers further West, only the nasal part of the compound has been retained (18). The island Sun is unique in recruiting the infinitive of bezañ be(a) 'to be'.

\footnotetext{
${ }^{5}$ The complementizer $h a(g)$ is involved in the left periphery of many constructions and is homophonous with the coordination marker.
} 
N'uion ket ma teuio.

N'uion ket la ma teuio.

N'uion ket lar teuio

neg'know not (that) if will.come

'I don't know if he will come.' Skaer/Bannaleg, H. Gaudart [04/2016b, 05/2016]

(17) N'oun ket hann ema chomet haoñ ba'n ger.

Neg'know not if is stayed he in'the home

'I don't know whether he stayed at home.' Kerne (Sant-Yvi), German (2007:174)

(18) Me meus ket soñj eñ vie puniset ar vugale. Le Juch, Hor Yezh (1983:21)

I I.have not memory if was punished the children

'I don't remember whether the children used to be punished.'

(19) Mendare be(a) eo gwir pe n'e ket ar pez e lavar.

I.wonder to.be is true or neg'is not the piece prt says

'I wonder whether what he says is true.' Enez Sun, Fagon \& Riou (2015:44)

The rules for relativisation are also subject to dialectal variation. Relativisation of an indefinite is known to be associated with the complex of two complementizers hag a (Kervella 1995:\$808) (20). In Central and Eastern Breton, sometimes only one vowel $/ \mathrm{a} /$ is realized. If only $h a$ is realized, we expect no mutation on the following verb, and if only $a$ is realized, we expect a lenition. It is unclear which of the two is realized in case of non-mutating verbs (see (21) vs. (22)). In the Leon dialect, hag a also appears for relativisation of a definite. The Leon grammarian Seite (1975:97) claims that when relativizing definites, hag $a$ is restricted to "when the clause is explicative, that is, not necessary for meaning". He illustrates with (23). Non-restrictive relatives of a definite indeed use hag $a$, as checked in corpus in (24). ${ }^{6}$

Yann a zo c'hrouadurhag a labour mat er skol. Yann prt is (a) child $\quad \mathrm{C}$ prt work well in.the school 'Yann is a child who works well at school.'

$$
\begin{array}{cccc}
\text { [jãn } & \text { zo } & \text { 'bygœl a labuкa 'mat bав } & \text { skol ] } \\
\text { Yann } & \text { 'zo } & \text { bugel a laboura mat e-barzh ar skol. }
\end{array}
$$

Yann (prt) is (a) child prt work well in (the) school

'Yann is a child who works well at school.'

Duault, Avezard-Roger (2004a:248)

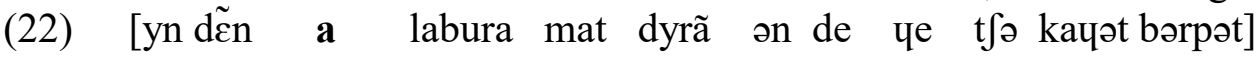

un den ha' laboura mat durant an deiz'vez ket kavet bepred.

a person $\mathrm{C} /$ prt works well during the day is not found always

'It is rare to find a person who works well the entire day.'

Gwenedeg (Kistinid), Nicolas (2005:50)

(23) An dén-se, $\quad$ hag a labour ken mad, a zo kenderv din.

the person-here $\mathrm{C}$ prt work so well prt is cousin to.me

\footnotetext{
${ }^{6}$ The use of the dialectally restricted relative pronoun pehini, pere seems to have disappeared before the first half of the twentieth century. In Modern Breton, where it is still grammatical, it signals an archaïsm or high speech level more than a dialectal variety in modern varieties (cf. "parfum désuet", Favereau 1984:263).

(i) ar walenn pehini 'ma reit tit bremañ zo seizh 'la so. the ring wh.one had.I given to.you now is seven year is 'the ring that I gave you now seven years ago.'
} 
'This person who works so well is my cousin.'

Leon, Seite (1975:97)

Va mamm hag a oa bet intañvez, he-doa daouvugel all.

my mother C prt was been widow 3SGF-had two children other

'My mother, who had been a widow, had two other children.'

Leon (Plouzane), Briant-Cadiou (1998:5)

The pre-Tense particles $a$ and $e$ show dialectal variation in their distribution. In all dialects, the particle is immediately before a tensed verb and its proclitics, and its identity is sensitive to the element that precedes it. These particles never appear before the verb emañ, in the imperative, optative and infinitive, nor after the complementizer $p a$ 'when, because'. Conservative dialects like Leon and Gwenedeg have two particles $a$ and $e$. The first one, $a$, appears after argument nominals. The second one, $e$, appears otherwise by default. In Leon, the $e$ form sometimes appear after A-bar objects as checked in elicitation with a relative in $(25)$ or $(26)^{7}$. The central area of the Kerne and Treger dialects has reduced the system to only one particle. Its phonological realization is mostly absent and seems random between $a$ and $e$. The rannig mostly triggers lenition (27), like $a$ would in other dialects, but it also sometimes erratically triggers the mixed mutation associated with $e$ (28). In the contact areas of these different systems, we can observe a gradation of variation. Finally, East Gwenedeg is unique in showing evidence for another higher particle en (Jouitteau 2009-2019:'en', Châtelier 2016:382).

(25) Koumpren mat a ran an traoù $\boldsymbol{e} / * a$ lavarez. understand well prt do.1SG the things prt say.2SG 'I understand well what you say.' Leon (Plougerneau), M-L. B. [01/2016)]

(26) A-wechoù, ar pezh a gaser ganeomp hon unan e/*a kaver barzh ar magajinoù. sometimes the part prt send with.us our one prt find.IMP in the shops 'Sometimes, we find in the shops what we brought.'

$$
\text { [ вак gyzin e'zebьајn ьак ] }
$$

Lesneven/Kerlouan, A. M. [05/2016] 'Barzh 'guizin e zebront bara.

Duault, Avezard-Roger (2004a:248)

in (the) kitchen prt eat bread

'They eat bread in the kitchen.'

[ ејn ${ }^{\mathrm{t}}$ a tibsi вак $\varepsilon$ в gegin] Int a tebr bara er gegin.

they prt eat bread in.the kitchen

(29) Gwir eo en en deus tud ar vro-mañ un digarez... Gwenedeg, Herrieu (1994:154) true is prt prt has people the country-here an excuse

'It is true that the people of this country have an excuse...'

\section{II.2. Verbal domain}

Dialects make use of a different set of modals. East Kerne dialects have a modal kas 'want, search' (cognates caes in the Leyden Manuscript, keissaw 'to search' in Welsh) that is unknown in other dialects, in which it is either understood as a dialectal form of

\footnotetext{
${ }^{7}$ Hendrick (1988: 105-6 note 2), and Rezac (2008:26) previously had noticed that in Leon, A-bar moved elements are associated with forms of the copula that are not compatible with the rannig $a$, like emañ or eo.
} 
klask 'to look for' (30), or kas 'to hate' (31). The syntactic structure is regular for a modal. By semantic competition, it impacts the distribution of the other modals. ${ }^{8}$

(30) Eman o c'houilia dre-holl kas kavout ar pez en deus kollet.

is at to.insect by-all want find the what he has lost

'He is looking around, trying to find what he has lost.'

" Dialectal », Académie bretonne (1922:293)

(31) Tout an dud atav 'gas gwel Kristiane.

All the people always wants to.see Kristiane

'Everybody always asks for Kristiane.' Duault, Avezard-Roger (2004a:412)

'Everybody hates to see Kristiane.' Standard reading

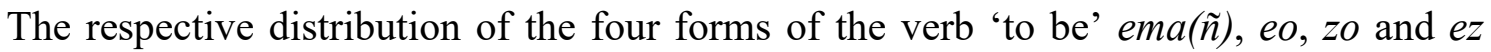
eus depend on a complex interaction of morphological, semantic and syntactic factors (Kervella 1970, Urien 1989). Verbal paradigms show different points of defectivity: Western dialects have no person restriction for the locative form ema(n) in the present tense, but Eastern dialects only have ema(ñ) for third person (Le Roux 1927, maps 63 to 65, Gros 1970:26, Favereau 1997:§416), as was the case in Middle Breton (Hemon 2000:§139(4)). Across all dialects, ema(ñ) is allowed as the first element in the sentence despite the language being persistently verb-second. The copula eo fills gaps in the paradigm of ema(n), but it is syntactically restricted to second position in the sentence. The defectivity of ema(n) thus impacts word order across dialects. In Gwenedeg or in

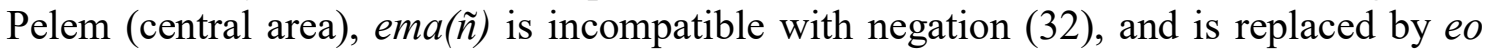
(Hewitt 1988a, Favereau 1997:§416). $\operatorname{Ema}(\tilde{n})$ is however compatible with negation in other KLT dialects, as illustrated for East Kerne (34). Western dialects from Kerne (Evenou 1987:626-38) to Ouessant can use the form ema(ñ) as an auxiliary, as documented in (33) to (35). This result is replicated in elicitation in (36).

(32) Ema ar bara àr an daol. vs. N-ê ket ar bara àr an daol.

Gwenedeg, Hewitt (1988a)

is the bread on the table neg-is not the bread on the table

'The bread is (not) on the table.'

(33) Bremañ emaint ambarket er vapeur adarre... Ouessant, Gouedig (1982) now are embarked in.the steam again

'They are still on the boat...'

(34) 'Ma ket degouezhet.

East Kerne (Rieg), Bouzeg (1986:35)

is not arrived

'He has not arrived.'

(35) Ema deuet Yann.

is come Yann

'Yann has arrived.'

(36) Kit da wel ma 'ma digouet ho preur. Skaer/Bannaleg, H. Gaudart [04/2016b] go for to.see if is arrived your brother

'Go see if your brother has arrived.'

The semantic environment attached to each form of the verb 'to be' varies across dialects (Kervella 1970). Predicative copulas can be found both under the ema and eo forms. In KLT dialects, the use of $e m a(\tilde{n})$ as a predicative copula induces firmer boundaries to the aspectual structure of its predicate than the eo form does (Davalan

\footnotetext{
${ }^{8}$ An anonymous reviewer signals that the verb kas is also known in Treger.
} 
1999, Avezard-Roger 2007:38, Goyat 2012:297, Gourmelon 2014:32), as shown in (37). This effect seems absent across Gwenedeg in (38) or (39).

/'ma:d ma ar ba:ra/ Mat ema ar bara good is the bread 'The bread is well cooked.' vs. /' ma:d $\varepsilon$ ar , ba:ra/ Mat eo ar bara good is the bread

'The bread tastes good.'

(38) /xa zo xi:rox ẃi-m-mand ledãn/

Groe, Ternes (1970:222)

Int zo hiroc'h evit m'emaint ledan.

they is longer for that are large

'They are longer than they are large.'
Brâs $\hat{\boldsymbol{e}}$ an $t i$
vs.
Neuse ema
big is the house
so is big the house

Plozévet, Goyat (2012:297)

'The house is big.'

The form ez eus is obligatory with an indefinite postverbal subjects in Leon (40). In Kerne and Treger however, such subjects trigger the form (a) zo (41). Gwenedeg shows alternations of both forms after bout, the infinitive of 'to be' that grammaticalized as an expletive (42). The same alternation is observed in passives whose subject is an indefinite in (43) and (44)). The dialectal variation here is more than morphological, because the optionality of the forms opens the door to contrasts in discourse.

(40) E ti an amezeien ezeus (/*zo) barbecue.

in house the neighbours prt is barbecue

Plougerneau, M-L. B. [04/2016]

'There is a barbecue next door.'

(41) War an daol zo paper. $\quad$ Treger and Kerne, Académie bretonne (1922:291) on the table is paper

'There is paper on the table.'

(42) Bout e zou/es $\underline{\text { avaleu. }} \quad$ Gwenedeg, Guillevic et Le Goff (1986:56)

to.be prt is apples

'There are apples.'

(43) Ar ar c'hanol eh eus graet pontoù.

on the canal prt is done bridges

'Bridges were done on the canal.'

(44) Kavet a zo doc'htu ur moranv dezhoñ: Fil-de-fer!

Herrieu (1994:104) found prt is immediately a nickname to.him Fil de fer

'A nickname is found for him right away: Fil-de-fer!'

In Western dialects, modals rankout 'must' and gallout 'can' optionally signal extraction of the object of its infinitival argument by an extra preposition $d a$ (45), whereas no such example emerges in Treger (46).

Ar Pont, gwir eo, a rankomp da weled.

Leon (Kleder), Seite (1998:63)

Ar Pont true is prt must to to.see

'It is true that we have to see Ar Pont.'

(46) Eun hantér-kant patatez am-eus ranket prenañ.

a half-hundred potatoes prt.I-have must to.buy

'I have had to buy a half-hundred potatoes $(25 \mathrm{~kg})$.'

Treger, Gros (1984:378) 


\section{II.2. Prepositional domain}

The inventory of prepositions varies across dialects. One can think of the cases of grammaticalization that give rise to new prepositions. Among many examples, in the island of Groe, da sellet/for to.see/ grammaticalized into the preposition dezit 'with respect to' (Ternes 1970:317) that is unknown elsewhere. The availability of a preposition in a dialect impacts semantic competition between the prepositions available in a given semantic environment, and this can affect syntax.

Prepositions can also be associated with different word orders. The most common privative preposition is hep 'without' (Le Roux 1927, map 320), but northern dialects also use anez, unknown in Southern dialects. Both prepositions behave alike when they head finite clauses: they are followed by the complementizer ma. However, when its object is a noun, anez is optionally followed by the preposition $d a$, which would be ungrammatical for hep ('without Rox', anez (da) Roks, hep Roks). Da follows hep only when its object is an infinitive clause (hep da Roks harzal 'without Rox to bark'). Anez, but not hep, can licence an empty object, allowing for adverbial uses (47).

Leon (Plouzane), Briant-Cadiou (1998:8)

Anez ehelled toulla ha sklabeza al lard a oa outo.

without.(it) prt can.IMP pierce and dirty the lard prt was on.them

'Otherwise one can pierce (the guts) and dirty the lart on them.'

We now turn to the inventory of functional prepositions. The premodern Breton system used to distinguish between the prepositions diouzh 'from' and eus 'from', ouzh 'to', and dimeuz 'of'. The Leon island of Ushant/Eusa retains a tripartite distinction between douh (E teued douh an noz 'On venait la nuit'), eus realized as such or as deus, and finally ouh (Gouedig 1982) ${ }^{9}$. In Plougerneau in Leon, the uses of diouzh and eus have merged under the preposition dac'h (48). In Central Breton, a single preposition deus subsumes all these prepositions (Académie bretonne 1922:292, and disapparition of dimeuz). In Gwenedeg, a preposition doc'h subsumes only the two prepositions diouzh and ouzh, but not the local equivalent of eus (realized as $a g$ ).

dac'h an uhelder dac'h ar mor.
diouzh an uhelder eus ar mor
from the height of the sea
'according to the height of the sea.'

Leon (Plougerneau), Elégoët (1982:8) premodern equivalent

The preposition expressing the agent of a passive is gant 'with' in KLT dialects (49), but $d a$ 'to' in Gwenedeg (50). This can be particularly misleading because, across all dialects, both prepositions $d a$ 'to' and gant, get 'with' also expresses an experiencer or an evidential as in (51) or (52). A logical guess for the interpretation of (49) by a Gwenedeg speaker would thus be 'According to some apprentice, each cake has been decorated'. Likewise, a KLT reading of (50) would be 'How many trees had been knocked down, according to the crazy wind!'.

Pep skotenn zo bet dekoret gant un apprenti bennak.

A. M. [05/2016]

Each cake is been decorated with a apprentice some Leon (Lesneven/Kerlouan)

\footnotetext{
${ }^{9}$ There is a form dor in Ouessant, but it corresponds to the preposition diwar 'from', based on or 'on', elsewhere war, àr (Gouedig 1982).
} 
'Each cake has been decorated by some apprentice.'

Nag a wez pilet $\boldsymbol{d}^{\prime}$ an avel foll!

Le Scorff, Ar Borgn (2011:7)

excl. of trees knocked.down to the wind crazy

'How many trees knocked down by the crazy wind!'

(51) Me 'zo o c'hober 'r c'hi gant hennezh. East Kerne (Rieg), Bouzeg (1986:V)

I is at to.do the dog with him

'He takes me for a dog.'

(52) Penegwir me a veze mezo dezo ordinal.

Treger, Gros (1970:157)

because I prt was drunk to.them always

'Because according to them I was always drunk.'

\section{II.2. Nominal domain}

The vast majority of dialects have only two paradigms of realized pronouns. On the one hand, the strong pronouns can appear in isolation in a hanging topic or under focus (me 'I, me') as in (53)a. On the other hand, pronouns without a topic or focus reading appear incorporated onto a morphological host, as is the case with prepositions (din 'to me', ganin 'with me'). In the Breton variety of Moëlan in East Kerne however, a third pronominal variety emerges in the first person singular. Speakers distinguish between a hanging topic pronoun meñ and another preverbal pronoun me more integrated into the clause as in (53)b.
a. Me, me a laboure da bemp eur.
b. Meñ , me labourè da beñb eur.
I I prt worked at five hour
'Me, I worked at five.'

\section{Standard \\ Moëlan}

Bouzec \& al. (2017)

In the nominal domain, articles are seldom pronounced in the central area (see German 1984 and Bouzec \& al. 2017:15 for East Kerne, Koadig 2010:48 for Goelo), with a weakening of differentiation between definites and indefinites (for Goëlo see Koadig 2010:25, for Treger see Le Dû 2012:43, for Central Breton in Duault and Kerne in La Forêt-Fouesnant, see Avezard-Roger 2007:40, fn38). ${ }^{10}$

$$
\begin{aligned}
& \text { [wa vjcX a wa m pot ] } \\
& \text { was MUT.girl and was a/the guy } \\
& \text { 'There was the daughter and there was the son.' }
\end{aligned}
$$

La Forêt-Fouesnant Avezard-Roger (2007:40)

Direct possessive constructions (the so-called construct state) are associated with absence of an article before the possessor in most dialects as in (55), except in some points of the extended central area. In Bear (Treger), Yekel (2016) observes that even if articles are seldom pronounced in this variety, the mutation system signals the presence of an article in front of the direct possessive constructions (cf. kambr 'room' in (56) and bazh 'stick' in (57)). This data is confirmed in two written corpora by native speakers

\footnotetext{
${ }^{10}$ An anonymous reviewer doubts the hypothesis that articles are not pronounced in the central area. He considers there is "a weak ictus, not perceived by French speakers". The evidence may indeed by partial for the heart of the central area. The rest of the data is however reported by Mona Bouzeg, Gary German and, to a lesser extend, Ronan Coadic in Goelo. Further research should provide comparative recordings rated by native speakers of the variety.
} 
(Croq 1908:62, (58), and in Lannuon in Treger, Stephens 2018, (59)). Some examples are also found in East Kerne (60), a variety which otherwise tends to drop articles. ${ }^{11}$
korn ar sal
corner the room
b. *ar c'horn ar sal
the corner the room

'the corner of the room'

(56) (ar) gambr ar vugale

Bear, Yekel (2016:'ar renadenn-dra')

(the) room the children

'the room of the children'

(57) Arri eo (ar) vazh ar paotr kozh!

Bear, speaker born in 1915, arrived is (the) stick the man old

Yekel (2016:'ar renadenn-dra')

'Here is the stick of the old man!'

ema ar zouben al leaz o vont war an daol.

is the soup the milk at going on the table

'The milk soup is served.'

en dro daol gegin ti unananezhe Lannuon, Stephens (2018)

'around the table kitchen of one of them'

'Ndorn m baël'nn zo tomm-ru.

East Kerne, Bouzec \& al. (2017:410)

the hand the frying-pan is hot-red

'The handle of the frying-pan is boiling hot.'

Synthetic demonstratives sometimes use an external plural morpheme across all dialects as in (61). Only Treger also drops the head noun (62), reinterpreting the deictic adverb se or $-m a(\tilde{n})$ as a nominal head.

ar re-ze(où), ar re-ma(où)

the N.PL-there.PL the N.PL-here.PL

'those, these'

ar seoù, ar maoù, (ar) maoùig

the there.PL the here.PL the here.PL.DIM

'those, these' Treger (Hewitt 2001, Le Dû 2012:71)

Dialects also differ in the extent to which they have lost the impersonal agreement marker $-r$ (63), the seventh person of Celtic paradigms (which is for example unknown in Langonned, Plourin 1982:664). This impacts word order because the dialects use different impersonal strategies like grammaticalization of the cardinal 'one' (64), or of an den 'the man'.

\footnotetext{
11 Possessive constructions preceded by an article have been reported in both Middle Breton and Premodern Breton. Hemon (1984:§29n1) has provided some examples like an thron an aelez 'the throne of the angels'. He analyses them as underlying prepositional structures, that is like the unattested thron a an aelez followed by coalescence of the preposition $a$ and the definite article $a n$. The example cited by Le Berre (2009:17) from 1622 in v. 15-16 of the Stabat Mater of Guéguen (an casty he map 'the distress of his son'), falls under Hemon's hypothesis. Hemon's analysis is consistent with synchronic data from Treger (Perroz), where the preposition is pronounced /a/, homophonous with the vowel of the fllowing definite article: an deiz kentañ a'r bloaz, /the day first of' the year/, 'the first day of the year' or an anv a'n $t i$, the name of' the house/, 'the name of the house' (Konan 2017: 'a'). However, Le Berre (2009:17) also notes that possessive constructions preceded by an article are found "frequently enough in the texts of the XIXst century, in archaïc constructions like an departamant Finister 'the departement of Finistère' or an aoutrou ' $\boldsymbol{n}$ escop Kemper 'sir the bishop of Kemper." In these last cases, the possessive is a proper noun and has no article, which a prepositional analysis could not account for.
} 
Atav vezer jalous deus o mamm.

Locronan, A-M.Louboutin [08/2014]

always is.IMP jaleous of their mother

'One is always jaleous of his own mother.'

/war ked' $\boldsymbol{\varepsilon}: \mathbf{n} /$

(Ne) oar ket unan.

Plozévet, Goyat (2012:242)

neg knows not one

'One does not know.'

(65) Ne oar ket (anin / an din) $)^{12}$.

neg knows not IMP / the man

'One does not know.'

Skaer/Bannaleg, H. Gaudart [04/2016b]

Dialects also differ as to the elements that an $-r$ impersonal can bind (Rezac \& Jouitteau 2015). In (63), the bound element is a 3PL (o mamm). It could also be 3SGM or 3SGF, but not 1SG. In North Leon, in an area including Kerlouan ha Kleder, one finds an incorporated impersonal pronoun -or inside the preposition estreget in (66)a. This preposition can be bound by an impersonal agreement marker, as in the case of eveldor in (66)b. In reflexive constructions, an impersonal definite determiner appears before the cardinal unan 'one' in (66)b. This structure is used by some the twentieth century authors : Ar Gow, Seite, Fave. It is still found in elicitation in the twenty-first century (Rezac \& Jouitteau 2015). This paradigm is unknown elsewhere (Jouitteau 2015), even in Leon. Kervella (1947:§436) mentions the reflexive form an unan, but recommends using 3SGM or 2PL forms when a pronoun is bound by a $r$-impersonal (Kervella 1947:§431, contra Fave 1943: 371, 1998 who insist an is the only correct impersonal form to him). ${ }^{13}$

(66)a. Estregedor a zo pinvidig.

Leon, Fave (1998)

except.IMP $\mathrm{R}$ is rich

'Others than oneself are rich.'

b. Ne gaver ket atao tud hegarad eveldor an-unan.

NEG find.IMP not always people kind like.IMP the(IMP)-one

'One does not always find people as kind as oneself.'

Emeer o sevel $\boldsymbol{e}$ di. Kerne, (Trépos 1968: §343)

is(L).IMP at building his house

'Someone is/people are building their house.'

I turn now to the inventory of expletive pronouns. We saw earlier that the form ez eus of the verb 'to be' signals a postverbal indefinite subject ((40)-(44)). This morphological reflex is obligatory in Leon. It is subject to variation in Gwenedeg. In both these dialects, ez eus provides the morphological evidence necessary to licences a postverbal indefinite null expletive (Rezac 2008:fn35). In this section, we will see cases where the form ez eus appears despite the absence of a realized indefinite subject. In (68), the agent of debriñ 'to eat' is not realized, but hte structure is not a passive. If the structure was a passive, it would have a definite postverbal subject, which is incompatible with ez eus. Instead, ez eus signals a null postverbal indefinite subject. The same holds in (69), where the hypothesis of a passive is not an option anyway, because the verb is

\footnotetext{
12 Some speakers use the form an nen, that shows the unusual nasal mutation found in dor, an nor 'the door'. I write here anin because the speaker H.G. explicitly asked me to do so. It could be a sign of pronominalisation (or not).

${ }^{13}$ The -or impersonal ending of prepositions is usually interpreted by hearers as a generic use of $2 \mathrm{PL}-$ $o X$, which can have the same impersonal interpretation.
} 
unaccusative. These structures are best analysed as expletive structures (There stayed only the bears, Il n'est resté que les ours). Verbal selection of the empty expletive shows, like in its French equivalent, a great deal of idiosyncrasy. The sentences of (68) and (70) have both been obtained in elicitation in a context where Goldilocks comes back home and discovers that an unknown person was there and has left traces in the house. The null indefinite expletive that was used in (68) is unavailable with the unaccusative verb dont 'to come' (70).

Amañezeus_drebet ar pladad a-bezh. Lesneven/Kerlouan, YM. [04/2016b] here prt is eaten the platter entirely

'The whole plateful has been eaten here.'

$N^{\prime}$ eus chomet nemed an ourzed.

Leon, Miossec (1980:70)

Neg is stayed only the bears

'Only the bears stayed.'

(70) Deuet ez eus (unan bennak) ${ }^{*}$ en va c'hear. Lesneven/Kerlouan, YM. [04/2016b] come prt is one some in my home

'Someone entered my house.'

The indefinite expletive appears also in existentials in (71) and meteorological constructions (72) despite the fact that no postverbal subject is realized. In other dialects, only the $z o$ form that is associated with a preverbal subject would be grammatical. This is also an alternative option for the speaker.

Pell amzer ez eus./ Pell amzer zo.

Lesneven/Kerlouan, A. M. [04/2016 $]^{14}$ long time is long time prt is 'It has been a long time.'

Glavezeus / zo.

rain prt is (prt) is

'It is raining.'

Lesneven/Kerlouan, A. M. [04/2016]

Finally, the null indefinite expletive is evidenced in association with propositional arguments. This is illustrated with a propositional infinitival argument in (73), and with a clausal complement in (74). The example in (75) shows idiosyncracy of the selection of the null expletive. It is allowed in association with the infinitive, but not as the subject of gallout, the modal 'can'.

(73) Kaer ez eus_ober lezennoù... Leon (Plouzane), Briant-Cadiou (1998 :229) beautiful prt is to.do laws

'Little point in making laws (but)...'

(74) An taol-mañivez eh eus gwelet petra a dalv an dud.

Vannetais, Herrieu (1994:98)

the time-here too prt is seen what prt means the people

'This time too, we see what people are worth.'

Ouessant, Gouedig (1982)

(75) Laret ez eus deom ober nebeutoh ma zo gellet a zegat. told prt is to.us to.do less that is modal of damage

'We have been told to make the least damage we can.'

\footnotetext{
${ }^{14}$ The same speaker hesitates more to use ez eus in the time construction.
} 


\title{
II.3. Agreement patterns
}

In all dialects, the verb kaout/endevout 'to have' is an exceptional verb. Morphologically, it is the only verb that can have its agreement morphemes appear on the left of the stem. Jouitteau \& Rezac $(2008,2009)$ have shown that this verb has different agreement rules from dialect to dialect. In Leon, kaout 'have' fully agrees with the phi-features of its subject, but usually to the exclusion of gender. In Gwenedeg, this verb agrees with pronouns, and not with lexical subjects (Guillevic \& Le Goff 1986:90, Ternes 1970:293). In Central Breton (Wmffre 1998:37,40), Treger (Leclerc 1986:76) and Kerne, kaout displays 3SG agreement with overt 3PL subjects, both independent pronouns (76)a. and lexical subjects (76)b. (vs. (76)c. showing full agreement with an empty subject).

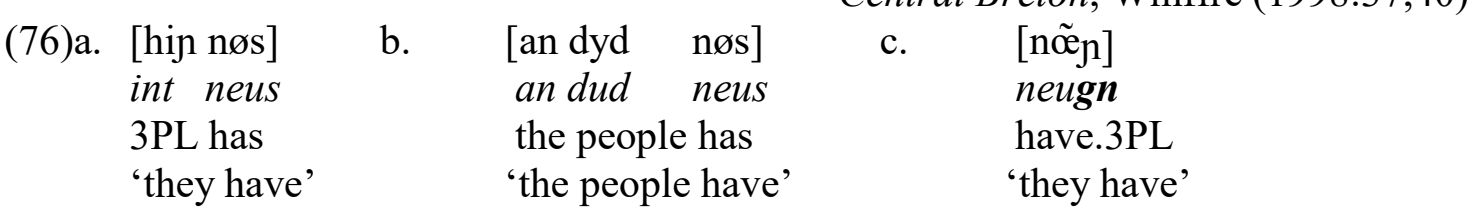

Verbs other than kaout/endevout show the "complementarity effect" by which they agree with their subject if and only if it is incorporated. Lexical subjects and nonincorporated pronouns trigger 3SG morphology on the verb (Jouitteau \& Rezac 2006 and references therein). The Plougerneau dialect in Leon is unique in optionally allowing 3PL agreement with a postverbal lexical subject as seen in (77) in corpus, and in (78) in elicitation. The 3SG agreement in (79) shows that in Plougerneau, the agreement system is otherwise regular, showing a complementarity effect.

\author{
Anvet oant tout ar gouverioù ganeomp. Plougerneau, Elégoët (1982:39) \\ named were all the channels with us \\ 'We had given a name to each channel.' \\ Louedañ a ra/reont buan ar c'hraoñ. \\ to.rot prt does/do fast the nuts.coll \\ Plougerneau, M-L. B. [01/2016] \\ 'Nuts rot fast.' \\ Ar c'hraoñv a goustoum(*ont) louedañ buan. Plougerneau, M-L. B. [01/2016] \\ The nuts.coll prt uses/*use to.rot fast \\ 'Nuts rot fast.'
}

In most dialects, a subject that appears before negation has its features reflected in agreement morphology (80). Certain southern dialects in Kerne and Gwenedeg however do not show this effect: in some varieties, agreement is optional (Stump 1984:293, n.2, Cheveau 2007:214), while in others it is obligatory as in (81).
Ar fubu $n^{\prime}$ int/*eo ket glas.
Leon (Plougerneau), M.L.B. the midges.coll neg are/*is neg blue 'The midges are not blue.'

Plogoneg, Roger Le Braz [06.2017]

(81) Evit dezho an dud neus desket brezhoneg ba'skol ne oar ket. for to.them the people has learned Breton in' school neg knows not 'For them, people.PL who have learned Breton at school don't know (it).' 


\section{II.4. Restrictions on syntactic movement}

Fronting of the progressive structure $[o+$ verb] is grammatical in Western Kerne (in Enez Sun, Kersulec 2016:27), Leon (in Kastell-Paol, Avezard-Roger 2004a:217), or Central Breton (in Duault, Avezard-Roger 2004a:281). In Eastern Kerne however, traditional speakers avoid fronting of this [o+verb] structure (Kennard 2013:179, 203). This phenomenon is verified here in elicitation in (82) and (83). The speaker is bilingual in Standard Breton and her native dialect of Eastern Kerne. She can front the standard form o kouezhañ in (82), but not its dialectal counterpart 'kouezho.

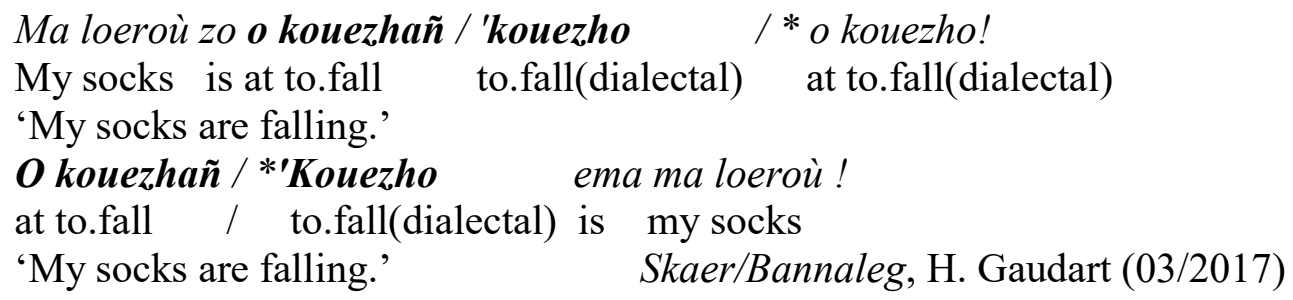

I turn now to resumptive pronouns anaphoric to the subject. All dialects make use of a prepositional paradigm of the type ac'hanon, anezhi, where a pronoun is incorporated inside the semantically empty preposition $a$-in order to form these subject resumptives. They appear across all dialects in equative constructions, as in (84). In northern dialects, they appear only here. Southern dialects also double the subject by a resumptive pronoun in structures like (85). These pronominal forms are not arguments of the verb and bring no extra reading (Stump 1984:44, Timm 1995). They are restricted to third person intransitives, and to negative contexts (Kervella 1947:§424, Guillevic and Le Goff 1986:131). However, these restrictions also vary. Subject resumptives are documented in non-negative contexts in the variety of Douarnenez (Denis 1977) and Le Juch as in (86), (87). They are documented in non-negative contexts with transitives in Sarzeau (Ernault 1878:233,59). The dialect of Saint-Yvi documented by German (1984, 2007) shows postverbal $a$ - forms of the subject without person restrictions as in (88). Remarkably in this dialect, the pronoun amounts to a real argumental subject for agreement; it triggers 3SG morphology, as a 3PL subject would in (89).

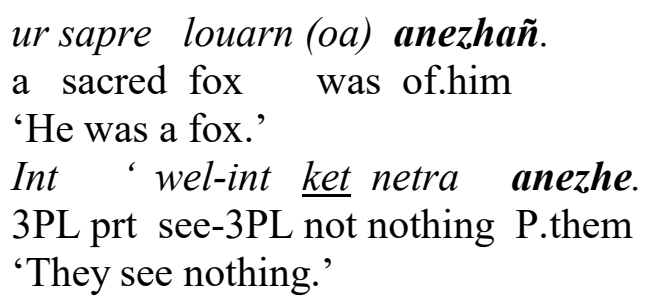

araok teuio honnezh d'ar gêr anezhi. Douarnenez, Timm(1995:21)

Setu e-giz-se ouie ken an dra-se anezhi. Le Juch, Hor Yezh (1983:21)

Standard

Nevez, Desseigne (2015:40) 
arrived is they

'They have arrived.'

I turn now to pronominal objects. The paradigm of $a$ - forms seen above for resumptives is recruited in most KLT dialects for postverbal object pronouns (90). Conservative dialects retain the older form of object coding, which uses proclitics on the verb (90) similar to possessive proclitics for most of the paradigm. In KLT, the proclitic form is still understood, thanks to old texts and traditional songs, but has an archaic flavour. For a speaker using proclitics however, the postverbal object incorporated into the preposition $a$ - is interpreted as partitive, which it was originally ('It is better to read (some/part) of them before.'). All central dialects use them as direct object pronouns, and their use spreads East and West. Quite surprisingly, these pronouns are banned from appearing in the preverbal position, even by way of focus movement that is normally available to lexical objects. Instead, a focalized object has to be realized as a strong independant pronoun (91). Central dialects are not uniform in this. Fronting of the postverbal form is possible (Hewitt 2001) as verified in (92) for Kastell-Paol.

\section{Gwelloc'h lenn anezho araok! \\ Gwelloc'h o lenn araok! \\ better 3PL read of.3PL before \\ 'It is better to read them before!'}

(C'hwi /*Ac'hanoc'h) am eus gwelet er marc'had ... Kerrain (2001)

you P.you prt.1SG have seen in.the market

'It is you I have seen in the market...'
Anezhi e welan.
P.her prt see.1SG
'I see her.'
Kastell-Paol, Avezard-Roger (2004a:419)

There is also dialectal variation as to the relative position of a past-participle and a lexical subject in the middle field. In East Kerne, participles appearing after the subject are ungrammatical or dispreferred, as confirmed in elicitation in (93). Most central dialects show optionality in this matter, with varying preferences. Rezac (2009) documents both orders used by the Bigouden (South-West Kerne) writer Yann Bijer. Chalm (2008:201), also native from Kerne, links subjects preceding the participle to a contrastive focus reading as in (94), which is not reported elsewhere. Participles before the subject are dispreferred (95) or rejected in Leon and Gwenedeg (Jouitteau 20092019: 'VXS' and references therein). This paradigm should be systematically investigated with proper controls for prosody and information structure.

(93) Dre he lost neus tapet Lucille ar c'hazh.

Skaer/Bannaleg, H. Gaudart [03/2017]

? Dre he lostneus Lucille tapet ar c'hazh.

by her tail has caught Lucille caught the cat

'Lucille caught the cat by its tail.'
$P$ 'he
doa Yulizh
torret
he brec'h
Kerne, Chalm (2008)
P'he
doa
torret Yulizh he brec'h
when'3SGF had YULIZH broken Yulizh her arm
'When Yulizh/YULIZH had broken her arm.'

(95) $\quad P a$ neus

Anna kroget el loa ...

Plougerneau, M-L. B. (05/2016)

? Pa neus kroget Anna kroget el loa... 
when has taken Anna taken in.the spoon

'When Anna took the spoon...'

\section{II.5. Interpretation and information structure}

The study of Breton semantics, pragmatics and information structure is not sufficiently developed to truly investigate dialectal variation in these domains yet, but their impact on the rest of the grammar has to be mentioned. Variation in information structure obviously leads to syntactic variation.

Third person pronouns $(h) e \tilde{n} v, h i,(h) / i n t$ are licit in Treger only under contrastive focus (Hewitt 2001), whereas they seem licit as subjects in neutral SVO orders in the other dialects.

Conventions of politeness toward the addressee vary across Brittany. Historically, Breton distinguishes 2SG familiar from 2PL polite forms to the adresse. The 2PL polite form was lost in the North, and 2PL forms are reserved to plural adressees. The 2SG form was lost in the South, leading to defective verbal and pronominal paradigms. The resulting morphological fossils can show feature mismatch, as illustrated in (96) for echo pronouns of emphasis.
(96)a. ho puoc'h-t-hu your cow-t-2PL 'your cow'

b.

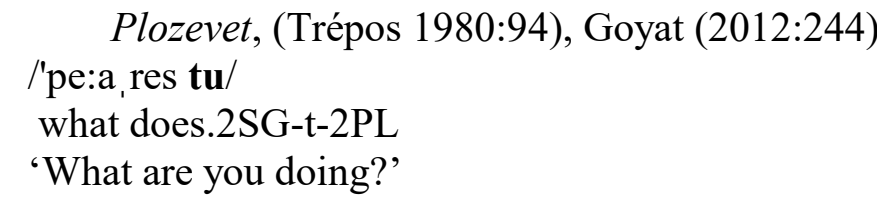

Possible readings of pronouns also vary in animacy. The demonstrative pronoun hennezh can refer to an inanimate in Treger (97), whereas it is restricted to animates in other dialects. In Ar Forest Fouenant, interrogative piv 'who' can refer to an inanimate (98), a reading reserved to the inanimate form petra in other dialects. Finally, in Ouessant in (99), an exclamative is realized with petra, in a manner similar to its English translation. In the other dialects, petra is the inanimate interrogative and (99) is ungrammatical.

(97) Hennez n'eo ti ebet.

this neg'is house any

'This is no( $\mathrm{t}$ a) house.'

Ma piv lakefen 'vit mont da fesen?

Treger, Gros (1984:197)

but what put.would.1SG for to.go to party

'But what could I wear to go to the party?'

(99) Petra plijadur!

Ar Forest Fouenant, Avezard-Roger (2004a:189)

what pleasure

'What a pleasure!' Ouessant, Gouedig (1982)

When considering dialectal differences, it is also important to stress that several points of variation may interact with each other. The insular dialect of Ouessant in the NW periphery, for example, can drop negation markers. Bare nouns usually need a negation marker to license them. In Ouessant, the dropping of negation has provided a favorable condition for the grammaticalisation of the bare noun tamm 'piece' into a negative word (100). For speakers of central dialects for which articles are seldom pronounced, tamm deñved in (100) is not a bare noun, and no negation marker contradicts their reading, thus leading to the opposite interpretation un tamm 'some'. Likewise, the dialect of An 
Ospital in Kerne has grammaticaled two adverbs that, under negation, mean '(not) a lot' (101). These adverbs are understood in other varieties as 'otherwise' and 'without order'. The negative polarity item nemeur '(not) a lot', used elsewhere, is not understood in An Ospital.

(100) Ar re 'doa tamm deñved a gave brao mond da zelled. the N.PL had piece sheeps prt found good go to watch 'Those who didn't have sheep liked to go watch.' Ouessant, Gouedig (1982)

(101) Ne oa ket aotramant/dizorden a dud er foarhirio. neg was not a.lot of people in.the fair today

'There was not a lot of people at the fair today.'

An Ospital (L'Hôpital-Camfrout), Le Gall (1957)

I conclude from the above that Breton dialects show robust variation at the syntactic level. The dialects vary as to the functional material available to them. The syntactic consequences impact agreement, rules of resumption rules, semantic interpretation of pronouns and information structure, as well as word order. Syntactic studies of Breton should take this dialectal variation into account. Scientific studies, even those that do not address linguistic variation, should clearly identify the dialectal source of their data to ensure replicability of their results.

In the following, I turn to the characterization of Standard Breton. Given the above results, the hypothesis that Standard Breton does not syntactically vary with respect to the traditional varieties can already be discarded. The traditional varieties show enough syntactic variation aong each other that no standard could comply to all and each of them. The remaining question is thus a quantification question. Is Standard Breton, as a dialect, more divergent from the traditional varieties than the traditional varieties are among themselves?

\section{Standard Breton with respect to the other dialects}

Standard Breton is described in normative grammars, prescriptive notes and learning methods (among many others, Académie bretonne 1922, Kervella 1947, Merser 1963, Davalan 2000, Kerrain 2001, Chalm 2008, Gourmelon 2014...). I follow Hornsby (2005) in considering Standard Breton as one of the Breton dialects. I investigate it as such from written corpora, as well as elicitations with speakers demonstrating native competence in it. Standard Breton is undeniably a KLT dialect, with inherent conservative features strengthened by a persistent influence from Leon, the NorthWestern variety showing the most conservative features of the KLT group.

\section{III.1. Rare forms from Leon}

Standard Breton can favour forms that are rare even in Leon. Such is the use of the complementizer eget in comparatives. Corpus and elicitation data shows that eget is attached to the periphery of conservative dialects (for Leon Plouider, Burel 2012:202; Plougerneau, Elégoët 1982; Bodilis, Ar Floc'h 1985:114; and for Gwenedeg Herrieu 1994:148). In Plogoneg in Kerne, Kergoat (p.c.) notes that eget is typical of the generation born before the First World War (102) that still used it in comparatives with gwelloc'h 'better' or gwashoc' $h$ 'worse'. Eget was replaced by evit in the younger 
generations. At the beginning of the twentieth century, when Le Roux asks for translations of plus fort que moi, 'stronger than me', the form eget is provided in extreme West Leon ; Landeda, Ouessant and Molène (Le Roux 1927:map 190). Even in these areas, eget now tends to be realized by different allomorphs (103). In the twentieth century, evit is reported even in islands like Groe (38). In the twenty first century, among traditional speakers, only some Leon speakers with low Standard influence still show spontanuous uses of eget (104). ${ }^{15}$

(102) gwelloc'h eget an dra-se ['gyæl:eYg3'nah:3 ] Plogoneg, Kergoat (c.p.)

better than the thing-here

'better than that'

(103) unan all hag e-noa muioh a ezomm negedonme. Ouessant, Gouedig (1982:88) one other that he-has more of need than.me-me

'Someone else who needed it more than I do.'

(104) Gwelloc'h e kaveratav eost an amezog eget da eost da-unan. better R find.IMP always harvest the neighbour than your(sg) harvest your(sg)-1 'One finds better the neighbour's harvest than one's own [lit. your own]'

In the vast majority of other traditional dialects, the preposition for superiority comparatives is now uniformly evit (gwelloc'h evit 'better than'), associating the use of eget to conservative forms, or to the Standard variety. The prescriptive use of eget can be favoured by an idea of preservation of morphological richness because the competing complementizer evit has a wide array of other established uses, including as the purpose preposition 'for'.

The bias towards Leon is noticeable in Standard, but not systematic. Standard Breton seems to treat the Leon dialect as a baseline that is permeable to other influences only when these are perceived as an enrichment of the baseline. Standard Breton for example adopted the postverbal object form ac'hanon, anezhañ instead of the proclitic forms (90) that were well installed in Leon, in order to favour existence of different speech levels.

\section{III.2. Preservation of morphological richness}

Standard Breton shows a global tendency to preserve morphological diversity. Defectivity in the paradigms seldom survives standardisation. One can see such a voluntarism at play in Kervella (1947:\$206), when the normative grammarian reproves defectivity for the impersonal form emeur of the locative/progressive form emañ of the verb 'to be', and its consequent suppletion by the impersonal form $e$ oar of the copula eo. Defectivity however is alive in his own native traditional variety, as illustrated in (105) with one of his own examples found some pages later.

(105) E oar oc'h hadañ an ed. prt is.IMP at planting the wheat

Kervella (1947:§ 231a)

Kerne (Dirinon) ${ }^{16}$

\footnotetext{
${ }^{15}$ Bouzec \& al. (2017:497) also report a local complex prepositional compound containing $h a(g)+$ evit in East-Kerne (Moëlan).

(i) koussoc'h adoñ/adous/ati/atoñ/adom/adoc'h/atè. older than.me/you.SG/her/him/us/you.PL/them

${ }^{16}$ Kervella is native from Dirinon, at the Leon border of Kerne, but his Breton is also influenced by the variety of Treger (Lannuon) and by various KLT influences.
} 
'One is planting wheat.'

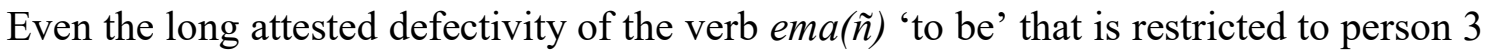
since Middle Breton (Hemon 2000:§139.4.fn1), and well-known in Welsh for its cognate (Favereau 1997: $\$ 416$ ), is rejected in Standard.

Voluntary preservation of morphological diversity is also observable in politeness rules. The preservation of the 2SG/PL address avoids morphological losses present in traditional dialects, even if it converges with French rules of address. Standard Breton also resists the generalist preposition deus that spreads from the central dialects. This phenomenon can be interpreted as a preservation strategy for the morphological material available, or as the result of the general bias of Standard Breton toward Leon. In some rare areas of Leon, the distinction between the three prepositions eus, ouzh and diouzh is indeed still alive even if most of the area shows a reduction in $d a c^{\prime} h$ and $d o c^{\prime} h$. Preservation of morphological richness is more a tendency than a rule. Gwenedeg features, like the differentiation of the two dynamic place interrogatives peban and emen, are not represented in Standard Breton. The Central Breton grammaticalisation of /how/ penaos into a declarative complementizer, exogenous to Leon, is also rejected despite its being attested since Middle Breton. Morphological richness, even if present in Leon, is also not automatically preserved in spoken Standard Breton. Leon forms emedo, evedo of the verb ema(ñ) 'to be' typically signal a written variety of Standard Breton or even an archaism, as does the paradigm of the simple past.

\section{III.3. Hypercorrections, avoidance of French-like structures}

The Breton lexicon is marked by hypercorrections (Moal 2004). Standard Breton syntax likewise shows signs of hypercorrections in word order. SVO order is perceived as typical of the dominant language French, leading to its voluntary avoidance. All traditional dialects however have neutral SVO orders (for Gwenedeg see Ternes 1970:253, Schapansky 1996, Cheveau 2007:210, for Kerne in Kemper see AvezardRoger 2004a:9, 367, 2004b and Kennard 2013:180, for Kerne in Plozevet see Goyat 2012:339, for Treger see Gros 1984:108). Traditional dialects show neutral fronting of both lexical and pronominal subjects. In (106), the subject bears old information that is already the topic in information structure, which shows that it bears no focus. Borsley \& Stephens (1989:417) have shown that subject initials are possible when the subject pertains to an idiom (107), which demonstrates that here no focus movement is involved. The preverbal subject in (108) has a favored narrow scope reading, which means that the easy reading is Every townhall now is such that a flag flies on it., and not ? There is now a flag such that it flies on every townhall. The subject is thus interpreted in his site before movement. This shows that the subject is not a topic. It is a property of topics that they are not interpreted in their base position: a topic subject would be restricted to the wide scope reading. The same reasoning applies to (109), where the context has enforced narrow scope reading (each table is such that a waiter has cleaned $i t$ ). If the subject was a topic, the only possible interpretation would be there is a waiter such that he cleaned each table. ${ }^{17}$

$$
\begin{aligned}
& \text { Leon (Plougerneau), M-L. B. [05/2016] } \\
& \text { (106) Mahouezane veho avel Nort, me a saro ar bouliji. }
\end{aligned}
$$

\footnotetext{
17 see Jouitteau (2007) for a formal analysis of neutral SVO orders and their derivation in the more general context of verb-second.
} 
if know.I prt will.be wind North I prt will.close the blinds

'If I know there will be Northern wind I will close the blinds.'

(107) Ar bik a c'hellfe kregiñ en e skouarn.

Treger, Borsley \& Stephens (1989:417)

the magpie prt could bite in his ear

'He could decide to get married.'

Skaer/Bannaleg, H. Gaudart [05/2016]

(108) Brom (ur banniel bennak) hich (ur banniel bennak) war pep ti-ker.

now a flag some flies a flag some on each townhall

'A flag now flies on every townhall.'

Leon (Plougerneau), M-L. B. [05/2016]

(109) Context: This dinner must have cost a lot: there were 17 tables and a waiter for each of them...

Ur servicher en deus renket pep taol.

A waiter prt has set.up each table

'A waiter has set up each table.'

(17 tables, 17 waiters)

In constrast, pedagogical Breton methods typically translate Breton SVO orders with hanging topics (Me a zo... Moi, je suis... 'As for me, I am...') or contrastive focus.

Hypercorrection is evidenced by Avezard-Roger (2004a:377), who shows that traditional speakers of KLT declaring strong emotional attachment to the language tend to produce less SVO in translations $(18,50 \%$ against $58,50 \%$ for declared weak attachment to the language and $53 \%$ for mild attachment to the language). It means that when they are more self-aware of word order, as in a translation task, they tend to avoid SVO orders. This is a clear sign of hypercorrection in Standard Breton by avoidance of subject initial orders.

Comparison with variation internal to the traditional dialects is in order: traditional dialects also vary as to their uses of SVO neutral orders. Avezard-Roger (2004a:367) finds that Central Breton speakers of Duault produce $20 \%$ to $30 \%$ of neutral SVO orders in translations from French, which is clearly less than what is found in Gwenedeg or Kerne. She also finds relatively few SVO orders in Kastell-Paol. However, in Plouzane on the other side of the Leon area, the corpus Briant-Cadiou (1998) is flooded with neutral SVO orders. In (110), all information is new in context, and focus is restricted postverbally to the argument of the focus marker hepken 'only'. The subject here is not even fulfilling the verb-second requirement, and still appears preverbal.

Plouzane, Briant-Cadiou (1998:39)

Gwechall archase a oa miret hepken evid an dud pinvidig.

Time.other the hunting prt was kept only for the people rich

'In the past, hunting was exclusive to rich people.'

Finally, in traditional varieties, neutral preverbal subjects also can be found in negative sentences. Kennard $(2013: 96,311,2014)$ obtains preverbal lexical subjects in negative sentences from an elicitation task with traditional speakers in Quimper. I confirm her results in (111) to (113), by the observation that impersonal pronouns can appear before negation. By definition, impersonals are semantically restricted to the background of the information structure (One doesn't know, but *It is one who doesn't know, *As for one, he doesn't know). In contrast, in Standard Breton, initial subjects before negation have to be focalized (Jouitteau 2010:418). 
(111) An nen ne oar ket bepred.

Rieg, Mona Bouzeg, c.p. (01/2009)

IMP neg knows not always

'One does not always know.'

(112) 'nnen 'ouia ket.

IMP (neg) knows not

'One does not know.'

(113) An nen ne glaska ket.

IMP neg searches not

East Kerne, Favereau (1997:§316)

'One does not look for (complications).'

Treger (Bear), Yekel (2016)

\section{III.4. Emergence of original properties?}

To my knowledge, there is only one candidate for an emergent property in Standard Breton that would have no counterpart in the other dialects. It concerns the nasal form of the 3SG of the locative/progressive verb 'to be' ema(ñ). In Western dialects, the nonnasal form ema has obligatory gender desambiguisation with empty subjects, giving

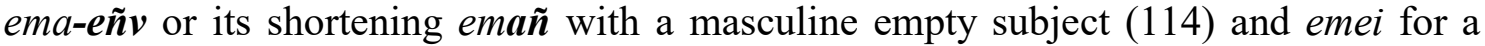
feminine one (115). In contrast, in Gwenedeg, ema is not gendered but no desambiguisation is obligatory (Merser 2011:93,fn2).

(114) [ n huitsik ma $\tilde{\text { j }}]$

Ar Forest Fouenant, Avezard-Roger (2004a:139)

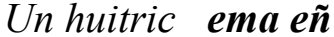

A Huitric is he

'He is a Huitric.' (a family name)

(115) [ ma hi 'lhenn o 'lheo $\left.{ }^{\circ}\right]$

Ema hi 'h lenn hoh leor.

is she at to.read your book

'She is reading your book.'

Saint-Yvi, German (2007:164)

In Standard Breton, the nazalized form emañ is interpreted as a gender neutral 3SG form, which Favereau (1997:§416) and Deshayes (2003:'ema') propose is a reinterpretation of ema-eñ in (114) as a new ungendered form of emañ. Availability of ungendered emañ leads to new syntactic possibilities where the nazalized form emañ can be desambiguized for gender again as in (116).

(116) Emañ eñ o vevañ e Bro an Tad Nedeleg!

Le Télégramme, 15.12.2005

is.3SG 3SGM at to.live in country the father Christmas

'He lives in the country of Santa Claus.'

However, emergence of a new form leading to new syntactic properties in spoken Breton is far from proven yet. First, the assumption relies on the idea that no traditional variety ever shows an ungendered use of emañ. Merser (2011:93,fn2) however reports that if emañ is the Western masculine form, use of emañ in Treger and East Kerne is ungendered, in which case Standard Breton is just mirroring here the modern central dialects. Second, the orthographic peurunvan convention imposes emañ as the only written 3SG form, and (116) could well in fact read ema-eñ as in the traditional Western dialects. The diachronic study of this phenomenon faces the same orthographic problem. Written forms with a nasal consonant are documented in pre-modern Breton. Hemon (2000:§139(4)) gives two forms in XVIII ${ }^{\circ}$ century Breton, éman, FG.:72 and in 
Treger eman, BD.:5004 without their syntactic context. In (117), it is unclear from the improvised orthographic system of the author if in this North Western dialect, a nasal form could indeed co-occur with a lexical subject or if Burel was mimicking an orthography taken from another syntactic context or even another dialect.

(117) héman anter lazet Yvon ganéoc'h. Breton 1905 (Plouider), Burel (2012:192) is half killed Yvon with.you 'You almost killed Yvon.'

\section{What neo-Breton is not}

The study is not advanced enough to provide a syntactic evaluation of the distance between neo-Breton and Standard Breton. However, the present approach already allows us to discuss some characterizations of neo-Breton that appeared in the literature (Hornsby 2005, 2014). In each case indeed, the facts that have been proposed to differenciate neo-Breton from Standard Breton are actually documented in traditional varieties.

Hornsby (2014) cites a note from Davalan (2000) on the existence of verb-third orders in neo-Breton. These word orders are however found across all traditional varieties (Jouitteau 2009-2019: 'V3'). Hornsby (2005:198) also remarks the neo-Breton use of the copula $z o$ after the expletive or verum focus particle bout, 'to be' (118). Bout zo... before an indefinite subject however is found in traditional varieties: Treger (Le Bozec 1933:6), Gwenedeg (Guillevic et Le Goff 1986:56) and East Kerne (Skaer/Bannaleg, H.G. 04/2016b) as we saw in (41). Hornsby (2005:198) also mentions a neo-Breton use of the copula $z o$ with a postverbal indefinite subject (119). We saw in (42) that this pattern is observed in all the central area from Treger to Kerne (Académie bretonne 1922:291, Kervella 1970:59, Favereau 1997:443, Chalm 2008:C7144, Goyat 2012:297). Some examples are also found in Gwenedeg in Herrieu.

\begin{tabular}{|c|c|c|}
\hline Boud zo & trous er-maes & $\mathrm{NeO}$ \\
\hline $\begin{array}{l}\text { Boud ezeus } \\
\text { to.be is }\end{array}$ & $\begin{array}{l}\text { trous er-maes } \\
\text { noice in.the-outside }\end{array}$ & Standard Breton, Hornsby $(2005: 198)$ \\
\hline 'There is noic & e outside'. & \\
\hline Amañ zо & trous & $\begin{array}{l}\mathrm{NeO} \\
\text { Standard Buton Hornchu }(2005 \cdot 100\end{array}$ \\
\hline Amañ ez eus & trous & Standard Breton, Hornsby $(2005: 198)$ \\
\hline $\begin{array}{l}\text { here is } \\
\text { 'There is noic }\end{array}$ & noice & \\
\hline
\end{tabular}

As documented so far, when native young adults deviate from literary Standard Breton, as they do from the Leon dialect, they actually show convergence with the traditional speakers of the central dialects. Influence of these innovative central dialects is expected considering that the only Breton immersive Diwan high school of the country is located at the heart of the central area in Karaez. More research has to be done in order to evaluate transmission of spoken Breton to the new generations of natives.

\section{Conclusion}


Standard Breton can be characterized as a new dialect of Breton, and illustrates the general tendencies of Standard dialects across languages (bias toward one of the traditional dialects, preservation of morphological richness, hypercorrections avoiding structures of the dominant language), but it does not stand out among Breton dialects as the most exotic of all. As far as I could discuss here, there is no clear evidence for the emergence of syntactic properties that would be unique to Standard Breton. At the syntactic level at least, Standard Breton does not stand as more exogenous to other dialects than the Leon dialect itself. Standard Breton is syntactically distinguishable from the traditional dialects, but it deviates minimally from them considering a context where syntactic differentiation is considerable between the traditional dialects, Kerne, Leon, Goelo, Treger and Gwenedeg. Much remains to be done concerning the proper characterization of syntactic microvariation, in particular for what concerns the new emerging varieties spoken by the generations of natives that have received schooling in Breton. The above results provide a baseline for such further research, and already allows for a clarification of the debate that has far-reaching consequences, even for sociolinguistic approaches.

\section{Bibliography}

Académie bretonne. 1922. 'Conseils de l'Académie Bretonne aux Ecrivains Bretons', Buhez Breiz 17, 149-154 \& 21, 290-294.

Le Roux, Pierre. 1927. Atlas Linguistique de la Basse-Bretagne, IV vol. available on line http://sbahuaud.free.fr/ALBB/, acronyme ALBB.

Avezard-Roger, Cécile. 2004a. Description syntaxique du syntagme verbal en breton: approche dynamique, thèse, Université René Descartes.

Avezard-Roger, Cécile. 2004b. 'Proximité linguistique entre breton standard et breton dialectal et entre breton et français : le cas des structures verbales', Jean-Michel Eloy (éd.) Des langues collatérales: Problèmes linguistiques, sociolinguistiques et glottopolitiques de la proximité linguistique, Paris: L'Harmattan, II:485-494.

Avezard-Roger, Cécile. 2007. 'Les verbes «être » en breton', La Linguistique 43:1, 2947. [10.3917/ling.431.0029. DOI].

BD., Ar Varn Diwezhañ, manuscript.

Le Berre, Yves. 2009. 'A propos du Stabat Mater breton de Tanguy Guéguen (1622) : le "moyen-breton" existe-t-il ?', Nelly Blanchard, Ronan Calvez, Yves Le Berre, Daniel Le Bris, Jean Le Dû, Mannaïg Thomas (éds.), La Bretagne Linguistique $14,13-24$

Le Berre, Yves \& Jean Le Dû. 2015. 'Devoir et nécessité : à quoi sert le breton à ceux qui le parlent?', Mannaig Thomas \& Nelly Blanchard (éds.), La Bretagne Linguistique 20, CRBC.

Ar Borgn, Herri. 2011. Brezhoneg ar Skorv, Trésors parlés du val de Scorff, Skol Vreizh.

Borsley, R. D. \& J. Stephens. 1989. 'Agreement and the position of subjects in Breton', Natural Language and Linguistic Theory 7, 407-427.

Bouzec, Mona, Jos Goapper \& Yannick Souffez. 2017. Le breton des rives de l'Aven et du Bélon, Blaz ha blazig c'hoazh, Dastumad Teñzor ar brezhoneg, An Alarc'h embannadurioù.

Bouzeg, Mona. 1986. A-dreñv ar pojoù, mémoire de maîtrise, Roazhon II.

Le Bozec, 1933. Le français par le breton, méthode bilingue, cours préparatoire, E. Thomas (ed.), Guingamp. 
Briant-Cadiou, Yvonne. 1998. E skeud daou dour ar barrez, Emgleo Breiz - Brud Nevez.

Burel, Hervé. 2012. Histor eur famill eus Brë̈s-Izel, Histoire d'une famille de BasseBretagne, traduit et présenté par Nelly Blanchard, CRBC, Skol Vreizh.

Chalm, E. 2008. La Grammaire bretonne pour tous, An Alarc'h embannadurioù.

Châtelier, Antoine. 2016. Traductions et variabilité en langue bretonne: l'exemple des traductions bretonnes de "l'Introduction à la vie dévote" (XVIIIe - XXe), thèse Rennes II

Cheveau, L. 2007. Approche phonologique, morphologique et syntaxique du breton du grand Lorient, $\mathrm{PhD}$. Thesis.

Croq, E. 1908. Klenved ar medalennou gant an Aotrou Fistoulik, pez-c'hoari fentus e tri arvest, Sant-Brieg, Ti moulerez Sant-Gwilherm.

Davalan, N. 1999. 'Interférences linguistiques chez des enfants scolarisés en breton', Francis Favereau (éd.), Le Bilinguisme précoce en Bretagne, en pays celtiques et en Europe atlantique, Actes du Colloque international de Plésidy (Côtes-d'Armor) octobre 1997, Klask 5, Presses universitaires de Rennes, 97-118.

Davalan, N. 2000. Brezhoneg hentenn OULPAN 1, Skol an Emsav.

Denis, Pierre. 1977. Étude structurale d'un parler breton: Douarnenez, unpublished thesis ms., Université de Rennes II.

Desseigne, A. 2015. 'Etude de la microvariation en breton. Enquêtes à Trégunc et Névez (Sud-Finistère)', Denis Costaouec \& Tanguy Solliec (éds.), Actualité de la recherche sur le breton et les langues celtiques, jeunes chercheurs, Emgleo Breiz, 20-46.

Elégoët, Fañch. 1982. Bezhinerien en enezeier, Hor Yezh.

Ernault, Émile. 1878. 'Le dialecte vannetais de Sarzeau', Revue Celtique III: 46-59, 232239.

Le Dû, J. 2012. Le trégorrois à Plougrescant, dictionnaire breton-français/français Breton, Emgleo Breiz, Brest, 2 vol.

Elégoët, Fañch. 1982. Bezhinerien en enezeier, Hor Yezh.

Evenou, Erwan, 1987. Description phonologique du breton de Lanvenegen (canton du Faouet, Cornouaille), thèse Rennes II.

Evenou, Erwan. 1989. 'Description phonologique du breton de Lanvénégen', Klask 1, Rennes : PUR, 17-55.

Fagon, Christian \& Yann Riou. 2015. Trésors du breton de l'île de Sein: bredoneg ar gear, on teuzeur, An alarc'h embannadurioù.

Falc'hun, F. 1951. Le système consonantique du breton avec une étude comparative de phonétique expérimentale, thèse, Rennes: Plihon.

Fave, Visant. 1998. Notennou yezadur, Emgleo Breiz.

Favereau, Francis. 1984. Langue quotidienne, langue technique et langue littéraire dans le parler et la tradition orale de Poullaouen, thèse de doctorat, Université Rennes II.

Favereau, Francis. 1997. Grammaire du breton contemporain, Morlaix: Skol Vreizh. FG., Paskal Kerenveier (ed.), 1941. Ar Farvel Goapaer, Sterenn 6, Brest.

Fleuriot, Léon. 1982, 'Les langues de Bretagne, aperçu sur l'histoire du breton', Brekilien, Yann (éd.), La Bretagne, Paris, Les Editions d'organisation, 245-324.

Ar Floc'h, Loeiz. 1985. Va zamm buhez, Lesneven, Mouladurioù Hor Yezh.

Ar Floc'h, Yann. 1950. Koñchennoù Eus Bro ar Ster Aon, Levrdi Le Dault - Kemper.

Le Gall, Charles. 1957. 'Le Vocabulaire breton de l'Hôpital-Camfrout', Annales de Bretagne 64:4, 445-473. 
German, Gary. 1984. Une étude linguistique sur le breton de St. Yvi, unpublished thesis ms, U. Brest.

German, Gary. 2007. 'Language Shift, Diglossia and Dialectal Variation in Western Brittany: the Case of Southern Cornouaille', The Celtic languages in contact: papers from the workshop within the framework of the XIII International Congress of Celtic Studies, Bonn, July 2007, Hildegard L. C. Tristram (ed.), Postdam.

Gourmelon, Yvon. 2014. Yezhadur!, Alioù fur evit ar vrezhonegerien diasur, Keit Vimp Bev, Laz.

Gouedig, Patrig. 1982. Enez-Eusa, Eñvoriou tud Eusa, mémoire de maîtrise, Brest.

Goyat, Gilles. 2012. Description morphosyntaxique du parler breton de Plozévet (Finistère), manuscrit de thèse, Rennes 2.

Gros, Jules 1970. Le trésor du breton parlé I. Le langage figuré, Ar Falz. [first edition 1966].

Gros, Jules. 1984. Le trésor du breton parlé III. Le style populaire (Éléments de stylistique trégorroise), Barr-Heol, Lannion: Giraudon. [first edition 74].

Guillevic, A.; Le Goff, P. 1986. Grammaire Bretonne du Dialecte de Vannes, Brest: Ar Skol Vrezoneg- Emgleo Breiz.

Hemon, Roparz. 2000. Yezhadur istorel ar Brezhoneg/Grammaire historique du breton, Hor Yezh.

Hemon, Roparzh. 1984. A Historical Morphology and Syntax of Breton, Mediaeval and Modern Breton series, The Dublin Institute for Advanced Studies.

Hendrick, Randall. 1988. Anaphora in Celtic and Universal Grammar, Dordrecht: Kluwer.

Herrieu, Loeiz. 1994. Kammdro an ankoù, Al Liamm (ed.). [first edition 1974].

Hewitt, Steve. 1988a. 'Ur framm ewid diskriva syntax ar verb brezoneg / Un cadre pour la description de la syntaxe verbale du breton', La Bretagne Linguistique, 4:20311 .

Hewitt, Steve. 2001. 'Notes sur le breton du Tregor', unpublished ms.

Hewitt, Steve. 2016. 'The problem of neo-speakers in language revitalization: The example of Breton', presentation at the International Conference on Endangered Languages, Tbilisi State Univeristy, Georgia.

Hor Yezh (ed.). 1983, Ur Vuhez war ar maez, Hor Yezh.

Hornsby, Michael. 2005. 'Néo breton and questions of authenticity', Estudios de Sociolingüística 6(2):191-218.

Hornsby, Michael. 2014. 'The "new" and "traditional" speaker dichotomy: bridging the gap', International Journal of the Sociology of Language 231:107-125.

Hor Yezh (éd.) 1983, Ur Vuhez war ar maez, [transcripts of six conversations with two native speakers of the Douarnenez region].

Jackson, Kenneth. 1967. A Historical Phonology of Breton, Dublin, DIAS.

Jones, Mari C. 1995. 'At what price language maintenance? Standardization in Modern Breton', French Studies 49 (4): 424-438.

Jones, Mari C. 1998a. Language Obsolescence and Revitalization, Linguistic Change in two Sociologically contrasting Welsh Communities, Oxford, Clarendon Press.

Jones, Mari C. 1998b. 'Death of a Language, Birth of an Identity: Brittany and the Bretons', Language Problems and Language Planning 22(2), 129-42.

Jouitteau 2009-2019. ARBRES, site de recherche sur la syntaxe formelle de la microvariation syntaxique de la langue bretonne, http://arbres.iker.cnrs.fr. 
Jouitteau, Mélanie. 2007. 'The Brythonic Reconciliation: From V1 to generalized V2', Craenenbroek and Rooryck (éds.), The Linguistics Variation Yearbook, Netherland, 163-200. pdf sur lingBuzz/000681.

Jouitteau, Mélanie. 2015. 'Pronoms impersonnels dans le breton vannetais de Loeiz Herrieu : Syntaxe, sémantique et usages en concurrence avec le passif', Mannaig Thomas \& Nelly Blanchard (éds.), La Bretagne Linguistique 19, CRBC, 261-280.

Jouitteau, Mélanie \& Milan Rezac, 2008. 'From mihi est to have across Breton dialects', Paola Benincà, Federico Damonte and Nicoletta Penello (éds.), Proceedings of the 34th Incontro di Grammatica Generativa, Unipress, Padova, special issue of the Rivista di Grammatica Generativa, vol. 32., 161 - 178.

Jouitteau, Mélanie \& Milan Rezac. 2009. 'Le verbe 'avoir' à travers les dialectes du breton', La Bretagne Linguistique 14, Nelly Blanchard, Ronan Calvez, Yves Le Berre, Daniel Le Bris, Jean Le Dû, Mannaig Thomas (éds.), 115-142. Brest: Centre de Recherche Bretonne et Celtique.

Jouitteau, Mélanie \& Milan Rezac. forthcoming/2016. 'Fourteen syntactic and semantic tests for Breton collectives, Number and numerosity', Lapurdum volume. [accepted 2016].

Kennard, Holly Jane. 2014. 'The persistence of verb second in negative utterances in Breton', Journal of Historical Linguistics 4:1, 1-39.

Kennard, Holly Jane. 2013. Breton morphosyntax in two generations of speakers: evidence from word order and mutation, DPhil. University of Oxford.

Kerrain, Mark. 2001. Ni a gomz brezhoneg gwell pe well: Ar fazioù stankañ graet gant an nevezvrezhonegerien [nous parlons Breton à qui mieux mieux: les erreurs les plus fréquentes chez les néobretonnants], Sav-heol.

Kersulec, Pierre-Yves. 2016. 'Un evezhiadenn bennak diwar-benn ar stumm-lec'hiañ ha stummoù all ar verb bezañ e brezhoneg an Enez-Sun [Quelques remarques relatives aux formes situatives et aux autres formes du verbe être dans le breton de l'île de Enez Sun]', Hor Yezh 285, 5-65.

Kervella, F. 1947. Yezhadur bras ar brezhoneg, 1947 édition Skridoù Breizh, La Baule ; 1995 edition Al Liamm.

Kervella, F. 1970. 'Ur gudenn gasaus : implij A ZO hag EZ EUS, A ZO hag EO, EO hag EUS', Hor Yezh 63 :53-60.

Koadig, Ronan. 2010. Brezhoneg Goeloù, Dastumad teñzor ar brezhoneg, An Alarc'h.

Konan, Gireg. 2017. Eostad, Dastumad Teñzor ar brezhoneg, An Alarc'h Embannadurioù.

Al Lay, Fañch. 1925. Bilzig, Buhez Breiz.

Leclerc, Louis. 1986, Grammaire Bretonne du dialecte de Tréguier, third edition, Ar Skol Vrezoneg, Emgleo Breiz, Brest. [first edition 1906].

Merser, A. 1963. Grammaire Bretonne, seconde édition revue et augmentée.

Miossec, Yves. 1980. Dreist ar Mor Bras, Brud Nevez 34-35, 66-72.

Moal, Stefan. 2004. 'Purism in Breton: rather death than taint?', Thomas Stolz \& Dónall Ó Riagáin (éds.), Purism in the age of globalisation: second helping, Bochum, Diversitas Linguarum vol.6, Université Brockmeyer, 73-98.

Nicolas, Michel. 2005. Yezhadur ar brezhoneg komzet e Kistinid hiriv-an-deiz, master's thesis, ms. Université Rennes II.

Plourin, Jean-Yves. 1982. Description phonologique et morphologique comparée des parlers bretons de Langonnet (Morbihan) et de Saint-Servais (Côtes-du-Nord), thèse de doctorat, Université Rennes II.

Rezac, Milan. 2008. extensive ms. of Rezac 2011. 'Building and interpreting a nonthematic A-position: A-resumption in English and Breton', Alain Rouveret 
(éd.), Resumptive pronouns at the interfaces, Language faculty and beyond, Benjamins. 241-286.

Rezac, Milan \& Mélanie Jouitteau. 2015. 'The Breton inflectional impersonal', Xulio Sousa, Carlota de Benito \& Víctor Lara (éds.), Syntactic variation in western European languages, from the noun phrase to clause structure, Dialectologia special issue $\mathrm{V}, 261-292$

Schapansky, Nathalie. 1996. Negation, Referentiality and Boundedness in Breton, a case study in markedness and asymmetry, ms thesis.

Seite, Visant. 1975. Le breton par les ondes, tome 2, Emgleo-Breiz.

Seite, Visant. 1998. O pourmen dre Vreiz-Izel, Levrenn genta. Emgleo Breiz.

Skragn, Jean-Marie. 2002. Ma buhez e Kêr ar Vinaoued, Emgleo Breiz.

Stephens, Janig. 1982. Word order in Breton, Ph.D. thesis, School of Oriental and African Studies, University of London.

Stephens, Janig. 1990. 'Non-finite Clauses in Breton', Celtic Linguistics: Readings in the Brythonic Languages, Ball, Fife, Poppe, Rowland, Celtic Linguistics: Readings in the Brythonic Languages Festschrift for T. Arwyn Watkins, Current Issues in Linguistic Theory 68, Benjamins, 151-166.

Stephens Bodiou, Janig. 2018. 'Honno', ms. submitted to Al Liamm, p.c.

Stump, Gregory T. 1984. 'Agreement vs. incorporation in Breton', Natural Language and Linguistic Theory, 2:289-348.

Ternes, Elmar. 1970. Grammaire structurale du breton de l'Ile de Groix, Carl Winter, Heidelberg.

Timm, Lenora. 1995. 'Pronominal A-forms in Breton: A discourse-based analysis', Journal of Celtic Linguistics 4:1-34.

Trépos, Pierre. 1968. Grammaire bretonne, Impr. Simon, Rennes. [reed. 1980 Grammaire bretonne, Ouest-France, Rennes.]

Trépos, Pierre. 2001. Grammaire bretonne, Impr. Simon, Rennes. [first edition 1968].

Urien, Jean-Yves. 1989. 'Le verbe "bezañ" et la relation médiate', Klask 1: 101-128.

Yekel, Tangi, Riwal Georgelin \& Juluan Ar C'hozh. 2015-2018. Brezhoneg Bro-Vear, Blog kevredigezh Hent don. https://www.brezhonegbrovear.bzh/index.php.

Whalley Neil. 2008-2015. 'to be', http://www.old-north.co.uk.

Wmffre, Ivan. 1998. Central Breton. [= Languages of the World Materials 152] Unterschleißheim: Lincom Europa. 